\title{
LAND-OCEAN COUPLING OF CARBON AND NITROGEN FLUXES ON SANDY BEACHES
}

\author{
Ecosystems (2009) 12: 311 - 321 \\ Thomas A. Schlacher ${ }^{1 *}$, Rod M. Connolly ${ }^{2}$ \\ ${ }^{1}$ Marine Science, Faculty of Science, Health \& Education, University of the Sunshine Coast, QLD- \\ 4558; ph+61 409 066710, Email tschlach@usc.edu.au \\ ${ }^{2}$ Australian Rivers Institute - Coast \& Estuaries, and School of Environment, Gold Coast campus, \\ Griffith University, QLD 4222, ph +61 (0)7 555 28614, Email r.connolly@griffith.edu.au \\ * corresponding author
}

\begin{abstract}
Rivers link oceans with the land, creating global hot spots of carbon processing in coastal seas. Coastlines around the world are dominated by sandy beaches, but beaches are unusual in that they are thought to rely almost exclusively on marine imports for food. No significant connections to terrestrial production having been demonstrated. By contrast, we isotopically traced carbon and nitrogen pathways leading to clams (Donax deltoides) on beaches. Clams from areas influenced by river plumes had significantly different isotope signatures $\left(\delta^{13} \mathrm{C}\right.$ : $-18.5--20.2 \% ; \delta^{15} \mathrm{~N}$ : $8.3-10.0 \%$ ) to clams remote from plumes $\left(\delta^{13} \mathrm{C}: 17.5-19.5 \%\right.$; $\left.\delta^{15} \mathrm{~N}: 7.6-8.7 \%\right)$, showing that that terrestrial carbon and sewage, both delivered in river plumes, penetrate beach food webs. This is a novel mechanism of trophic subsidy in marine intertidal systems, linking the world's largest shore ecosystem to continental watersheds. The same clams also carry pollution signatures of sewage discharged into rivers, demonstrating that coastal rivers connect ecosystems in unexpected ways and transfer contaminants across the land-ocean boundary. The links we demonstrate between terrigenous matter and the largest of all marine intertidal ecosystems are significant given the immense social, cultural and economic values of beaches to humans and the predicted consequences of altered river discharge to coastal seas caused by global climate change.
\end{abstract}

Key-words: land-ocean coupling, sandy shores, food webs, trophic subsidy

\section{INTRODUCTION}

Ecosystems typically receive materials from outside of their boundaries (sensu Cole and others 2006). Such cross-boundary transfers can profoundly modify the dynamics of recipient systems in numerous ecosystem types (Cadenasso and others 2003). Fluxes of materials, energy and organisms that transcend ecosystem boundaries provide a potent conduit for linking landscape elements (Cadenasso and others 2004). Theoretical frameworks of meta-ecosystems that incorporate spatial connectivity integrate perspectives of community and landscape ecology, and provide a useful conceptualisation of ecosystem functioning, dynamics and stability (Loreau and others 2003). 
Flows of nutrients and organic matter link production and consumption processes, and recipient systems typically become energetically connected to donor systems via trophic subsidies (Polis and others 1997). Theory indicates that trophic subsidies can strongly influence population dynamics, predator-prey interactions and food webs (Loreau and Holt 2004), and ecologists increasingly recognise their fundamental structuring role (Marczak and others 2007). Significant effects of subsidies span a wide range of ecological organisation, including: (a) stimulating primary productivity (Schlacher and others in press-b), modifying vegetation structure (Ellis and others 2006), (b) increasing the abundance and biomass of consumers (Stapp and Polis 2003; Paetzold and others 2006; Marczak and others 2007), (c) modulating predator-prey interactions (Knight and others 2005; Schlacher and Cronin 2007), (d) altering the dynamics of spatially-coupled food webs (McCann and others 2005), and (e) fuelling ecosystems metabolism (Rubbo and others 2006; Pace and others 2007).

Aquatic-terrestrial ecotones join physically well-bounded ecosystems (Post and others 2007). Material fluxes do, however, transcend the land-water boundary in numerous settings, and cross-boundary transfers substantially modify ecological processes in lakes (Pace and others 2007), streams (Burdon and Harding 2008), wetland ponds (Rubbo and others 2006), estuaries (Chanton and Lewis 2002), and on marine shores (Polis and Hurd 1996).
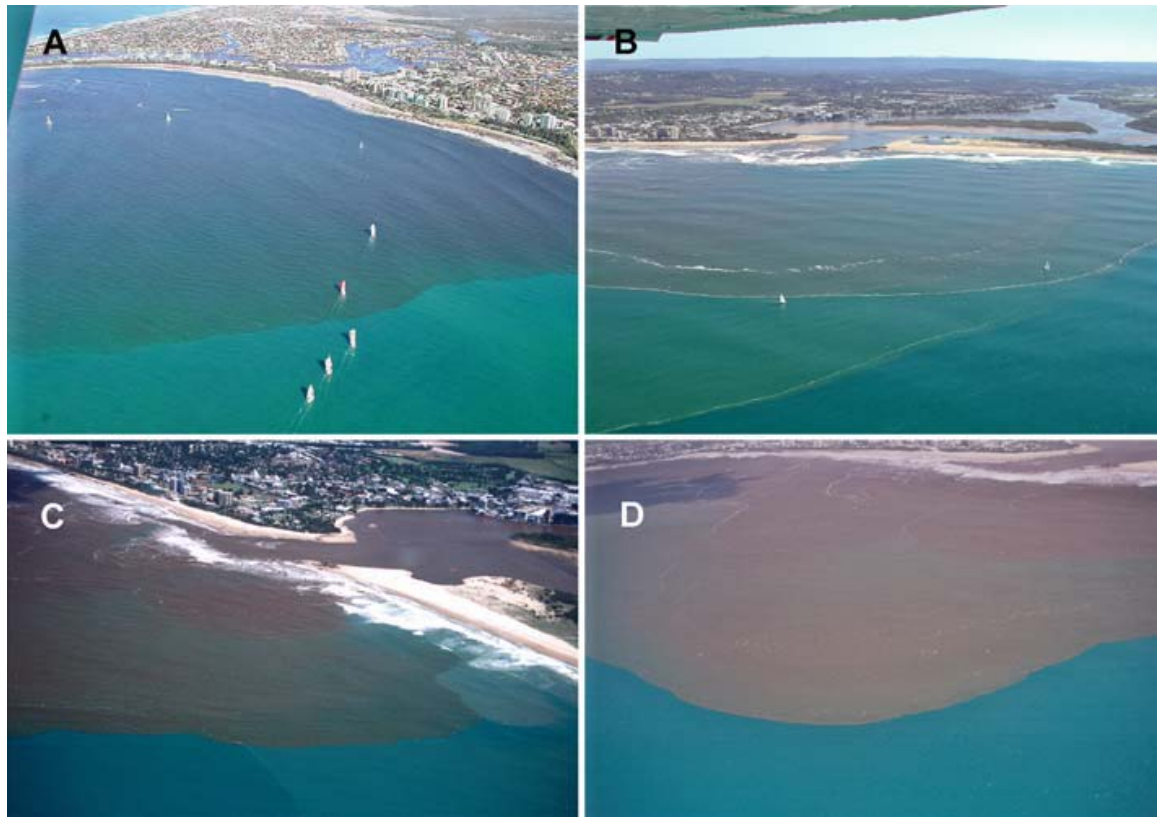

Figure 1 Examples of river plumes exporting large amounts of terrestrial sediment, carbon, and nitrogen to coastal oceans. Plumes are created by episodic, strongly pulsed rainfall events (cf. Fig. 5), and are characterised by highly distinct water masses and sharp boundaries in the nearshore zone. Note that plume waters can impact on sandy beaches adjacent to estuarine inlets, supplying terrigenous material as energetic subsidies to food webs, and transferring estuarine pollutants (sewage) to sandy shores. All aerial images show plumes for the systems investigated in this paper in Eastern Australia. (A - Mooloolah River, 18 May 2003; B - Maroochy River, 18 May 2003, C \& D - Maroochy River, 07 March 2004).

The land-sea boundary is considered a critical transition zone (Levin and others 2001). Fluxes of materials carried in river discharges rank amongst the largest cross-boundary fluxes globally (Schlünz and Schneider 1999). Coastal seas impacted by river discharges are the oceans' hotspots for the processing of terrestrial material transferred from land to the sea. Large quantities of sediment and carbon deposited by rivers in coastal margins fuel disproportionately high rates of material transformations that account for $90 \%$ of 
modern carbon burial, thereby impacting global bio-geochemical cycles (McKee and others 2004). The most important biogeochemical reactions in these systems are associated with the decomposition of terrestrial organic carbon exported to the sea (Schlünz and Schneider 1999).

Many rivers discharge turbidity plumes to coastal seas (Fig. 1). Plumes enrich coastal waters with inorganic nutrients, they enhance biological production and fisheries yields, and they create a distinct biogeochemical imprint on the seafloor (Gillanders and Kingsford 2002; Dagg and others 2004; Gaston and others 2006). Thus, plumes are the key functional link that couples terrestrial and marine systems in many coastal regions.

Sandy beaches are the single largest coastal ecosystem on earth, covering $70 \%$ of all continental margins (McLachlan and Brown 2006). Beaches are of immense social and cultural importance to humans as prime recreational assets: more people interact directly with beaches than with any other type of shoreline worldwide (Schlacher and others 2007c). Sandy beaches mostly lack biological structure, are physically controlled environments, and support little in-situ primary production; their food webs therefore rely heavily on imports from marine sources (McLachlan and Brown 2006).

Interface regions between aquatic and terrestrial ecosystems are biogeochemical hot spots in the biosphere (McClain and others 2003), and sandy shore ecosystems can support some of the highest metabolic rates measured (Coupland and others 2007). Because beaches are prime examples of terrestrial-aquatic ecotones, they would thus be predicted to play a pivotal role in the processing and transfer of organic matter. In fact, sandy beaches can provide trophic subsidies to terrestrial food webs in situations where marine resources are transferred to terrestrial consumers (Polis and Hurd 1995; 1996; Anderson and Polis 1998; Stapp and Polis 2003). However, a reverse pathway of material exchange across the land-beach ecotone (i.e. transfer of terrestrial production to beaches) has not been reported to date.

Studies of material processing through beach food webs have historically ignored the potential role of trophic subsidies from river discharges. Yet, many sand beaches are either bounded or intersected by estuarine inlets that discharge river plumes (Fig. 1). Thus, river plumes can impact on sandy shores and supply terrestrial material to their food webs, thereby coupling the largest of all intertidal ecosystems to continental production through carbon and nitrogen pathways. Thus, the specific hypothesis tested in this study was that terrestrial trophic subsidies operate on sandy beaches via the delivery of land-derived production in river plumes.

We investigated the transfer of terrestrial material to beaches by measuring the incorporation of terrestrial $\mathrm{C} \& \mathrm{~N}$ isotopic signals $\left(\delta^{13} \mathrm{C} \& \delta^{15} \mathrm{~N}\right)$ in wedge clams, Donax deltoides (Lamarck, 1818). Stable isotopes provide an effective measure of relative contributions of terrestrial and marine matter because they typically have distinct isotopic ratios (Peterson and Fry 1987). For carbon, this occurs either because plants have different photosynthetic pathways or because they obtain carbon from air rather than water. For nitrogen, the variation in isotopic signatures usually results from the effects of widespread changes in catchment land-uses, in particular urbanisation (McClelland and others 1997). Since the isotope end-members of the broad source categories, terrestrial and marine, are reasonably well known, stable isotope analysis can detect riverine input to coastal waters (Darnaude and others 2004, Wissel and Fry 2005). Nitrogen isotopes are also used to investigate the incorporation of anthropogenic sources of nitrogen from developed catchments into marine food webs (Hansson and others 1997, Waldron and others 2001). 
Beach clams of the genus Donax are ideal model organisms to measure carbon and nitrogen transfers into beach food webs: the clams are highly efficient primary consumers, (Matthews and others 1989), comprise a significant portion of biomass on beaches (McLachlan and others 1996a), are instrumental in nutrient cycling (Soares and others 1997), and occupy a pivotal role in the trophic architecture of sandy shores (Ansell 1983).

\section{METHODS}

\subsection{Field sampling.}

We sampled wedge clams, Donax deltoides, on two exposed sandy beaches in southern Queensland on the East Coast of Australia. The first beach borders the Maroochy River which discharges highly turbid and nutrient-rich plumes through its estuarine inlet located at the southern end of the beach from which clams were collected $\left(26.65^{\circ} \mathrm{S}, 153.10^{\circ} \mathrm{E}\right)$. These river plumes occur as distinctly pulsed events and are usually confined close inshore. From aerial surveys and ship-based tracking of plume fronts (Gaston and others 2006), we determined that plumes disperse mostly in an offshore direction, but also impact on the adjacent sandy beach, either as part of the main plume or as lateral eddies that recurve and transport plume waters onshore. The watershed of the estuary is largely cleared for agriculture and housing. Substantial loads of wastewater enter the estuary, with sewage nitrogen $\left(47 \mathrm{t} \mathrm{y}^{-1}\right)$ amounting to $65 \%$ of the total nitrogen load (Schlacher and others 2005). Matching sets of clams were collected from an ocean beach remote from freshwater discharge. This marine reference site $\left(26.01^{\circ} \mathrm{S} 153.15^{\circ} \mathrm{E}\right)$ was $70 \mathrm{~km}$ north of the plume-impacted beach and $42 \mathrm{~km}$ from the nearest estuary, which is a small system that discharges only very small plumes not extending for more than $2 \mathrm{~km}$ alongshore.

Rainfall and river discharge in the region is strongly bimodal, with most of the annual precipitation falling during the austral summer which contrasts with the dry conditions during the austral winter. To test for temporal variation in the strength of land-ocean coupling driven by fluctuating river discharge, we collected clams before the main river discharge in early January 2004, after the wet season (May 2004), and at the end of the low-flow period in September 2004 (Fig. 5).

Clams (Donax deltoides) were hand-collected from the lower intertidal zone of the exposed beach during low tides; about 50-200 individuals were obtained per trip. The across-shore distribution of this species extends from the mid-intertidal to the swash and shallow parts of the surf- zone seawards (James and Fairweather 1995; Schlacher and Thompson 2007). As for other species of the genus Donax, the clams can actively adjust their position across the beach through swash riding (Donn Jr 1990; Ellers 1995). Abundances are also spatially heterogeneous in an along-shore direction: dense patches of 100-200 m length often alternate with sparse stretches along the beach, and this pattern can be related to variations in beach morphology (James and Fairweather 1996; James 2000). Donacid clams dominate the biomass on many sandy beaches worldwide, and constitute an important prey category for numerous invertebrates (e.g. crustaceans, gastropods), fishes and shorebirds (Ansell 1983; Salas and others 2001; Peterson and others 2006).

\section{Laboratory analysis}

To encompass the full size spectrum of the sampled clam population, we selected for isotope analysis the smallest and largest individual plus 8-12 additional specimens at equal size steps in between. A total of 233 clams were analyzed giving a sample size (n) for each time $x$ site combination of 10-14. Body size in the sampled population ranged from 10 to $54 \mathrm{~mm}$ shell length (mean $31.8 \pm 12.9 \mathrm{SE}$ ). From each individual, the foot tissue, adductor muscle and gills were excised. Tissues were rinsed twice in deionised water, decalcified (immersion in $1 \mathrm{M} \mathrm{HCl}$ for $40 \mathrm{~min}$ ), followed by four rinses in deionised 
water and drying at $65^{\circ} \mathrm{C}$ for $48 \mathrm{~h}$. Stable isotope ratios were measured in the Isotope Analytical Facility of Griffith University on an automated Isoprime Isotope-Ratio Mass Spectrometer. Stable isotope ratios are expressed in \%o using the conventional delta $(\delta)$ notation: $\delta X(\%)=\left[\left(R_{\text {sample }} / R_{\text {standard }}\right)-1\right] \times 1000$; where $X$ is $\delta^{13} \mathrm{C}$ or $\delta^{15} \mathrm{~N}$, and $\mathrm{R}$ is the ${ }^{15} \mathrm{~N} /{ }^{14} \mathrm{~N}$ (nitrogen) or ${ }^{13} \mathrm{C} /{ }^{12} \mathrm{C}$ (carbon) ratio in the sample and standards (Pee Dee Belemnite equivalent for carbon and the IAEA international standard of atmospheric $\mathrm{N}_{2}$ for nitrogen).

\section{Data analysis}

The main test of interest was the magnitude of isotopic differences between clams from areas impacted by river plumes versus those remote from plumes. Because the three tissue types analyzed originate from the same individual, they are multiple dependent variables. We therefore used a Multivariate Analysis of Variance (MANOVA) as the GLM model to partition variance in the full data set. This analysis included the terms: i) site (plume-impacted vs. marine-reference site), ii) time (low, medium, and high river discharge), and iii) the time $x$ site interaction. The MANOVA was complemented by twofactor ANOVAs for individual tissue types to assess whether detected effects are consistent amongst tissue types. To remove any possible confounding of body size on isotope ratios (i.e. independent of site and time), we standardized isotope ratios to the median length $(32 \mathrm{~mm})$ of clams using the slopes derived from regressions of size vs. $\delta^{13} \mathrm{C}$ or $\delta^{15} \mathrm{~N}$; slopes were computed for each tissue $\mathrm{x}$ site $\mathrm{x}$ time combination separately.

We estimated the relative contribution of terrestrial and marine carbon to clams using the IsoError mixing model (Phillips and Gregg 2001). For the terrestrial (including estuarine) source we used the $\delta^{13} \mathrm{C}$ of suspended particulate organic matter (SPOM) collected in the mid estuary (-25.15\% in summer, $-25.92 \%$ in winter). For the marine source, we considered that the tissue of clams at the reference (non-plume) site provided a more reliable isotope value, after making a $0.5 \%$ adjustment for fractionation (-19.20 \% in summer, $-19.95 \%$ in winter). Direct isotope measurements of marine SPOM were not used because the composition and isotopic signature of suspended particles in coastal waters vary markedly over short periods. Fluctuations in the mixing between onshore and offshore waters and changing inputs from a broad spectrum of allochthonous sources and autochthonous production are the main cause of this variability (Megens and others 2001; Hill and others 2006). This temporal variance in the chemical properties of suspended matter in coastal seas means that spot measurements of isotopic signatures in particulate matter extracted from water samples are generally unrepresentative of the actual carbon available to consumers, such as bivalves, over longer time periods. Given this mismatch in the temporal integration of isotopic signals (minutes to days for suspended particles vs. weeks to months for animal consumers), isotopic signals in SPOM samples generally do not track changes in the tissues of filter-feeding bivalves (Lorrain and others 2002; Hill and others 2006; Gustafson and others 2007).

\section{RESULTS \& DISCUSSION}

Clams exposed to river plumes had isotope ratios that were significantly depleted in ${ }^{13} \mathrm{C}$ and enriched in ${ }^{15} \mathrm{~N}$, an isotopic shift consistent with the incorporation of terrestrial carbon and nitrogen (Figs. 2-4, Table 1). Isotopic variation among beach clams was chiefly driven by spatial differences between clams from the marine reference and those from the plume-impacted area (MANOVA; site effect: df $=3,62 ; \mathrm{P}<0.001$; Table 1). The magnitude of the contrast (effect size) between plume and reference sites varied subtly through time, evident as a weak but significant interactive effect of time $x$ site (MANOVA; site $x$ time: $\mathrm{df}=6,124 ; \mathrm{P}<0.001$; Table 1 ), but the direction of the isotopic shift between sites never changed. Carbon isotope ratios were always significantly lower in clams from 
the plume area and nitrogen ratios always significantly higher (Figs. $3 \& 4$ ); this is in close agreement with a stronger terrestrial signal present in clams exposed to plume waters. Furthermore, this isotopic shift, indicating greater incorporation of terrestrial carbon and nitrogen by clams in the plume area, was highly consistent across the three tissue types analysed (i.e. foot, adductor muscle, gills; ANOVA: df =1,64; $\mathrm{P}<0.0001$ for all tissues and elements). Based on carbon isotopic mixing models (Phillips and Gregg 2001), clams in plume areas obtain a sizeable fraction of their body carbon from terrestrial sources; values of terrestrial carbon assimilation average 15\% (Cl: 3-28\%) across seasons, with a maximum of $18 \%(\mathrm{Cl}: 4-32 \%)$ at the end of the rainy season.

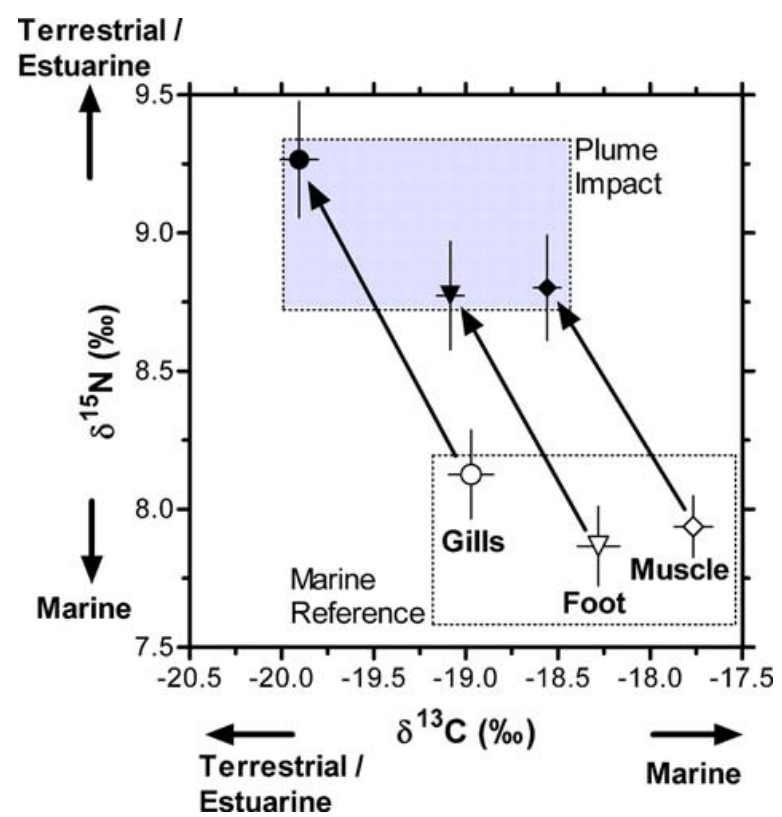

Figure 2 Shifts in carbon and nitrogen stable isotope ratios in three tissue types of wedge clams (Donax deltoides) exposed to river plumes on a sandy beach abutting an estuarine inlet. Clams from the marine reference area were collected from an exposed, ocean beach not affected by river plumes. Data are seasonal means (3 sampling periods corresponding to low, medium and high river discharge; c.f. Fig. 5) with 95\% confidence intervals.

The global flux of riverine organic carbon to the oceans of $434 \times 10^{6} \mathrm{tC}$ year ${ }^{-1}$ (Schlünz and Schneider 1999) is about $6 \%$ of coastal primary production at $6,900 \times 10^{6} \mathrm{tC}$ year ${ }^{-1}$ (Wollast 1991). Assuming that: i) $10 \%$ of the exported TOC is buried (Schlünz and Schneider 1999), that ii) particulate organic carbon (POC) represents $46 \%$ of the total terrestrial load (Ludwig and others 1996), and that iii) 65\% of the POC load is refractory (Ittekkot 1988), about $62.9 \times 10^{6}$ tonnes of labile POC with a terrestrial provenance are available for biological processing in the oceans worldwide. This 'bio-available' fraction of the total terrestrial carbon export from rivers represents about $1 \%$ of coastal production on a global scale.

Although there are many uncertainties in the estimates of global carbon fluxes, it is remarkable that our estimate of terrestrial carbon uptake $(-15 \%)$ by consumers on a sandy beach is an order of magnitude greater than the global average projected above. However, spatial heterogeneity in the energetic importance of plume subsidies is likely to be pronounced. Plume subsidies are predicted to be more important at local and regional scales along coastlines where river discharges are large, but much less so in arid regions with low river run-off or few plume areas. We hypothesized that the magnitude of terrestrial carbon delivery and trophic assimilation is higher in coastal regions impacted by river plumes than in areas not influenced by freshwater influence. Indeed, the uptake of 
terrestrial material we measured in marine consumers demonstrates the existence of an energetic link between coastal ecosystems and continental carbon sources. Importantly, the amount of terrestrial material assimilated by sandy beach animals that feed in plume areas is consistent with predictions about the putative strength of land-ocean coupling based on global estimates of terrestrial carbon flux to coastal seas and the biological processing of the material in marine systems affected by river plumes.

If anything, our estimate of terrestrial carbon incorporation by sandy beach bivalves may be conservative. Water-borne organic carbon particles with a depleted isotopic signature (i.e. material from terrestrial $C_{3}$ - plants and mangroves) can settle closer to their source, whereas isotopically enriched carbon (i.e. $C_{4}$ - grasses, such as sugarcane) is transported further offshore because of their smaller sizes (Goni and others 1997; Bianchi and others 2007). In situations where significant amounts of terrestrial $\mathrm{C}_{4}$-carbon mix with marine sources due to the hydrodynamic sorting of fluvial particles that differ in their isotopic signatures, the amount of terrestrial carbon incorporated by marine consumers may be underestimated. Thus, animals on beaches may assimilate greater amounts of terrestrial material than shown in an isotopic tracer study such as ours.

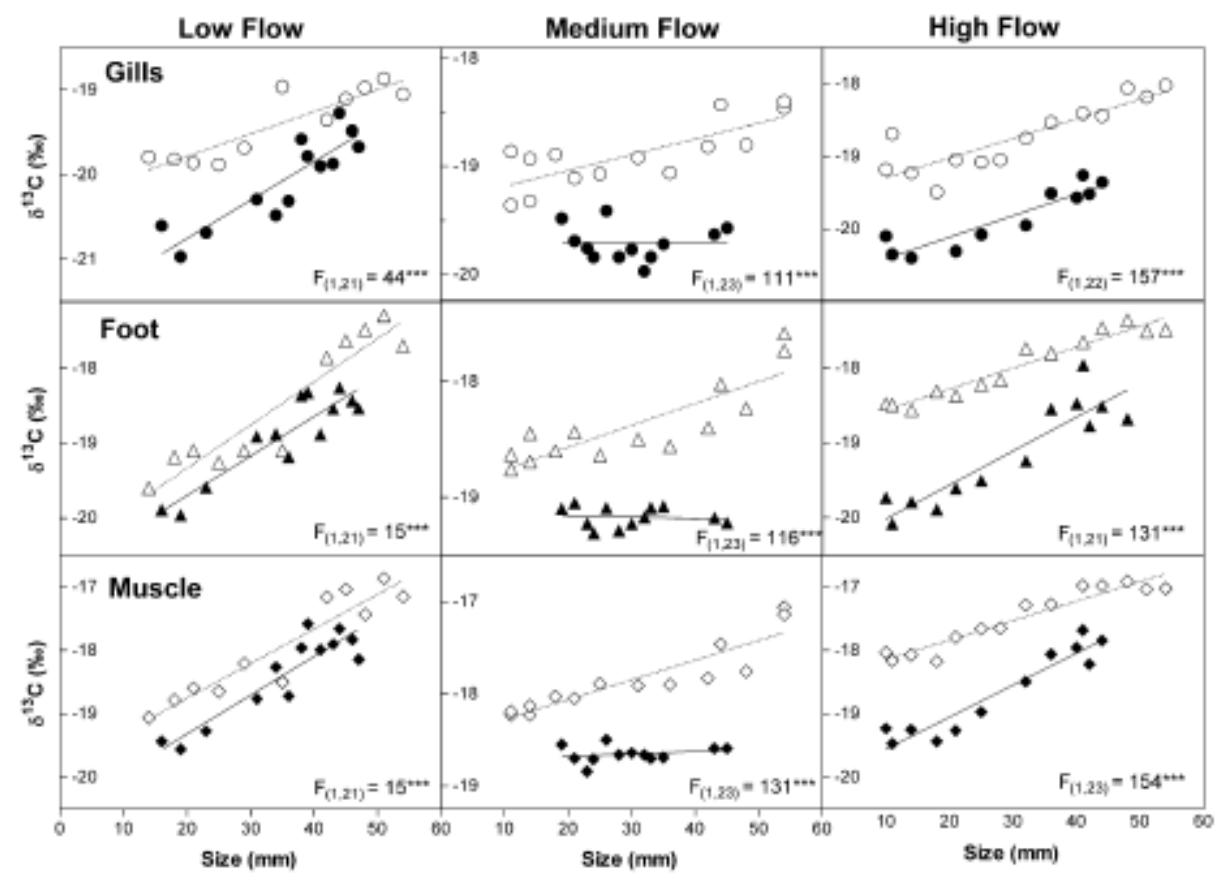

Figure 3 Spatial contrasts in stable carbon isotope ratios $\left(\delta^{13} \mathrm{C}\right)$ in three tissue types of wedge clams (Donax deltoides) between a sandy beach impacted by river plumes (solid symbols) and a marine reference site (open symbols) remote from the influence of river plumes. Contrasts are shown for three different periods of low river discharge (left column, Sep. 2004), medium discharge (centre column, Jan. 2004) and high river discharge (right column, May 2004). All site-to-site differences in carbon signals are significant (Analysis of Covariance - ANCOVA where body size is the co-variate) irrespective of time $\left({ }^{\star \star *} P<0.001\right.$, ${ }^{\star \star} P<0.01$, * $P$ $<0.05)$.

We detected a greater isotopic shift towards terrestrial carbon influence following peak river discharges (Fig. 5). This shows that after larger quantities of organic carbon were exported from the estuary, bivalves on the adjacent sandy beach had assimilated significantly more terrestrial carbon than during low-flow periods (Fig. 5). Conversely, during baseflow conditions, most of the nitrogen in the estuary originates from discharges of sewage that is enriched in ${ }^{15} \mathrm{~N}$ (Schlacher and others 2005). Nitrogen isotope ratios of clams on the adjacent beach tracked the export of this elevated sewage signal following low river discharge. This enriched sewage signal becomes diluted by run-off from the watershed during major rainfall events, producing $a{ }^{15} \mathrm{~N}$-depleted isotope signal in the 
river discharge (Schlacher and others 2005), which resulted in correspondingly lower enrichment factors in the clams (Fig. 5).

Detection of an isotopic change symptomatic of land-ocean coupling depends partly on the rates at which carbon and nitrogen are replaced in target consumers. Tissue turnover times in filter-feeding bivalves are species-specific and depend on tissue type, growth rates and metabolic activity of the animals; measurements range from 80 days in stomach glands of freshwater mussels (Raikow and Hamilton 2001) to 1 year in whole-body and adductor muscle of marine and freshwater mussels (Hawkins 1985; Raikow and Hamilton 2001). Bivalves exposed to plume waters would therefore integrate isotopic signals of terrestrial exports over periods of months to a year. Moreover, isotopic signals in consumer tissues are the product of metabolic replacement in combination with the addition of new carbon and nitrogen during growth. Tissue turnover in faster-growing juveniles is mainly driven by growth, with only a minor contribution of metabolic replacement (Zuanon and others 2006). Juvenile clams should therefore show higher rates of isotopic change in their tissues and respond more readily and strongly to major inputs of new terrestrial carbon supplied by the high river discharge during the austral summer and autumn (Jan to May, Fig. 6). This explains why the degree of isotopic shift between animals from the marine reference station and those from the plume was inversely related to body size (Fig. 4; OLS: $\Delta \delta^{13} \mathrm{C}=1.50+$ Size $x-0.0116 ; F_{(1,16)}=7.386$, $P=0.01)$. Juveniles had incorporated significantly more terrestrial carbon at the end of the rainy season compared to larger individuals, which had slower rates of carbon replacement. This differential response of juvenile and adult clams further supports our conclusion that isotopic patterns result from the uptake of terrestrial matter.

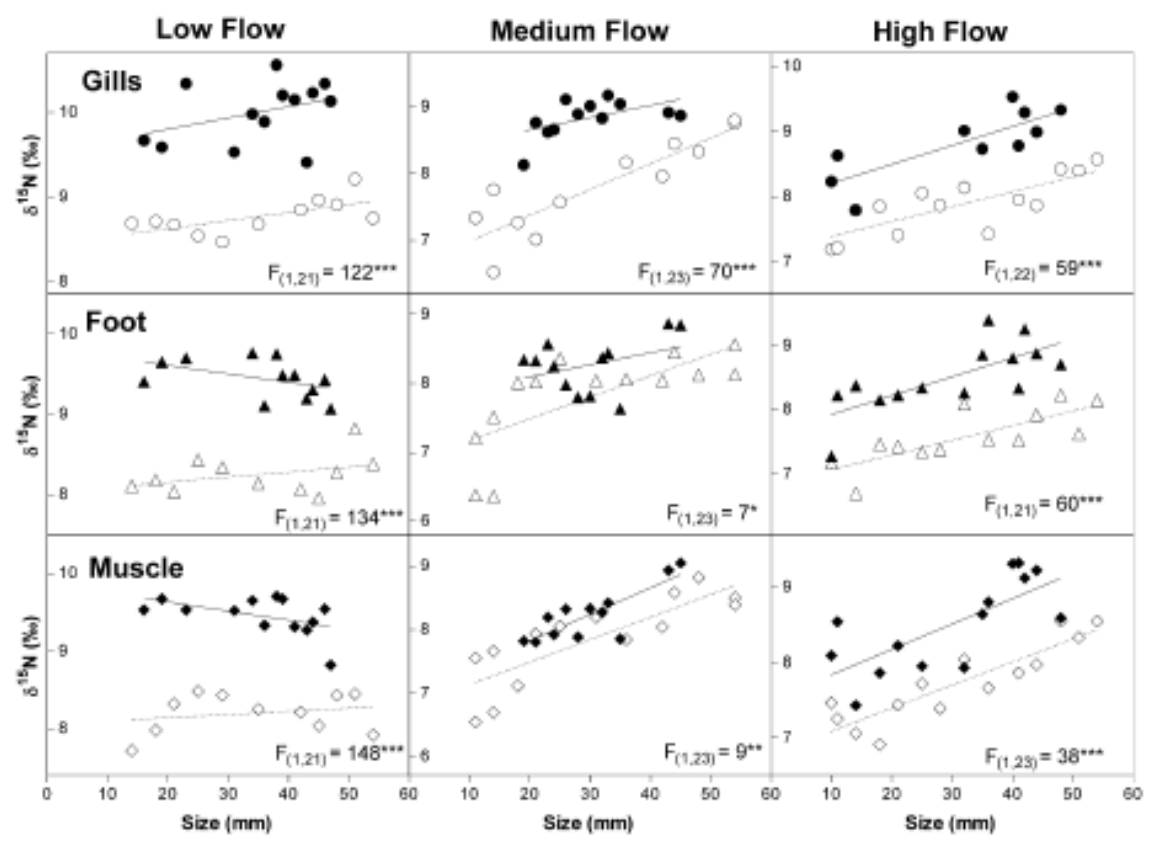

Figure 4 Spatial contrasts in stable nitrogen isotope ratios $\left(\delta^{15} \mathrm{~N}\right)$ in three tissue types of wedge clams (Donax deltoides) between a sandy beach impacted by river plumes (solid symbols) and a marine reference site (open symbols) remote from the influence of river plumes. Contrasts are shown for three different periods of low river discharge (left column, Sep. 2004), medium discharge (centre column, Jan. 2004) and high river discharge (right column, May 2004). All site-to-site differences in nitrogen signals are significant (Analysis of Covariance - ANCOVA where body size is the co-variate) irrespective of time $\left({ }^{\star \star *} P<0.001,{ }^{\star *} P<0.01,{ }^{*} P\right.$ $<0.05)$.

Conventional wisdom holds that food webs of sandy beaches are supported almost exclusively by marine imports (McLachlan and Brown 2006). Here we document for the first time that consumers on beaches can be linked to terrestrial carbon delivered by river 
plumes. This is a novel mechanism of trophic subsidy in marine intertidal systems. Marine bivalves play a pivotal role in carbon cycling in the coastal oceans. Dense populations of bivalves, common on sandy beaches, process large amounts of suspended carbon, regenerate nutrients, enhance the flux of organic matter to the seafloor, and mediate the trophic routing of pelagic primary production (Dame 1996).

Table 1 Summary of GLM model results to partition the total variance in carbon and nitrogen isotope ratios in wedge clams between sites (i.e. plume impact vs. marine reference) and times (i.e. three discharge periods, cf. Fig. 5), using (A) multivariate analysis of variance (MANOVA) as the main test, complemented by (B) univariate tests for individual tissue types ( ${ }^{\star * *} \mathrm{P}<0.001$, ${ }^{\star *} \mathrm{P}<0.01,{ }^{*} \mathrm{P}<0.05,{ }^{\mathrm{ns}} \mathrm{P}>0.05$ ).

\begin{tabular}{|c|c|c|c|c|c|}
\hline$\delta^{13} \mathrm{C}$ & $\begin{array}{l}\text { Wilks' } \\
\text { Lambda }\end{array}$ & F & & $\begin{array}{c}\text { Effect } \\
\text { df }\end{array}$ & $\begin{array}{c}\text { Error } \\
\text { df }\end{array}$ \\
\hline Time & 0.24 & 23.3 & $\star \star \star \star ~$ & 6 & 134 \\
\hline Site & 0.12 & 156.5 & $\star \star \star$ & 3 & 67 \\
\hline Time $x$ Site & 0.71 & 4.2 & $\star \star \star \star ~$ & 6 & 134 \\
\hline$\delta^{15} \mathrm{~N}$ & $\begin{array}{c}\text { Wilks' } \\
\text { Lambda }\end{array}$ & $\mathrm{F}$ & & $\begin{array}{c}\text { Effect } \\
\text { df }\end{array}$ & $\begin{array}{c}\text { Error } \\
\text { df }\end{array}$ \\
\hline Time & 0.187 & 27.14 & $\star \star \star \star$ & 6 & 124 \\
\hline Site & 0.149 & 118.28 & $\star \star \star \star ~$ & 3 & 62 \\
\hline Time $\times$ Site & 0.632 & 5.34 & $\star \star \star$ & 6 & 124 \\
\hline
\end{tabular}

\begin{tabular}{|c|c|c|c|c|c|c|c|c|c|c|}
\hline \multicolumn{2}{|c|}{ B - Univarlate } & \multicolumn{2}{|c|}{ Foot } & & \multicolumn{2}{|c|}{ Gills } & & \multicolumn{2}{|c|}{ Muscle } & \\
\hline$\delta^{13} \mathrm{C}$ & df & MS & $\mathrm{F}$ & & MS & $\mathrm{F}$ & & MS & $F$ & \\
\hline Time & 2 & 1.09 & 24.1 & 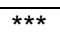 & 2.74 & 67.8 & 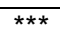 & 1.01 & 24.6 & $\star \star \star \star ~$ \\
\hline Site & 1 & 10.76 & 238.2 & *** & 14.54 & 359.5 & 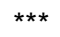 & 10.73 & 260.4 & 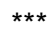 \\
\hline Time $\times$ Site & 2 & 0.55 & 12.1 & $\star * *$ & 0.16 & 3.9 & * & 0.36 & 8.7 & $\star * \star$ \\
\hline Error & 69 & 0.05 & & & 0.04 & & & 0.04 & & \\
\hline$\delta^{15} \mathrm{~N}$ & df & MS & $\mathrm{F}$ & & MS & $\mathrm{F}$ & & MS & $\mathrm{F}$ & \\
\hline Time & 2 & 4.78 & 44.1 & 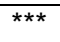 & 7.75 & 100.8 & 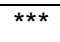 & 3.60 & 39.0 & 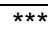 \\
\hline Site & 1 & 12.90 & 119.2 & $\star \star \star \star ~$ & 20.03 & 260.2 & $\star \star \star$ & 12.61 & 136.7 & $* \star \star$ \\
\hline Time $\times$ Site & 2 & 1.09 & 10.1 & $\star \star \star *$ & 0.15 & 2.0 & ns & 1.24 & 13.5 & $* * *$ \\
\hline Error & 69 & 0.11 & & & 0.08 & & & 0.09 & & \\
\hline
\end{tabular}

We used wedge clams (Donax deltoides) as a model system to test the strength of trophic coupling between terrestrial primary production and sandy beach food webs. Wedge clams were chosen because they are the dominant macroscopic consumer of suspended organic matter in the benthos of many beaches worldwide (Ansell 1983; Soares and others 1997), are highly efficient filter feeders (Matthews and others 1989), mineralise organic matter on beaches (Soares and others 1997), and form a critical energetic link to higher trophic levels such as shorebirds and fishes (Ansell 1983). Importantly, the clams can access the terrestrial carbon and nitrogen delivered by plumes via several routes: (1) uptake of phytoplankton production that has been stimulated by nutrients outwelled in plumes; (2) direct uptake of particulate organic matter (POM) exported by river discharge; (3) assimilation of carbon originally delivered in dissolved form and subsequently converted to particulate form in the prominent microbial loop of the surf zone and interstitial sediments (Cockcroft and McLachlan 1993); and (4) direct uptake of DOC, although this pathway may be inconsequential for marine species (Pan and Wang 2004). Based on the multiple roles that bivalves play in the processing of matter in benthic systems, we predict that the isotopic shifts of clams measured in this study will be 
detectable in other consumers and that they will propagate through most of the food web on sandy beaches impacted by river plumes.

Given the ecological importance of wedge clams, the incorporation of carbon and nitrogen from river plumes, which we document here as a novel mechanism of ecotonal coupling, is predicted to have several consequences that extend beyond the ecological organisation of the filter-feeding guild. 1) Energetic subsidies of keystone prey species by river discharge may profoundly influence ecosystem energetics on sandy shores, including trophic effects that cascade upwards to affect populations of threatened vertebrates on beaches. 2) River discharge has been linked to higher fisheries yields in coastal seas (Gillanders and Kingsford 2002); beach clams
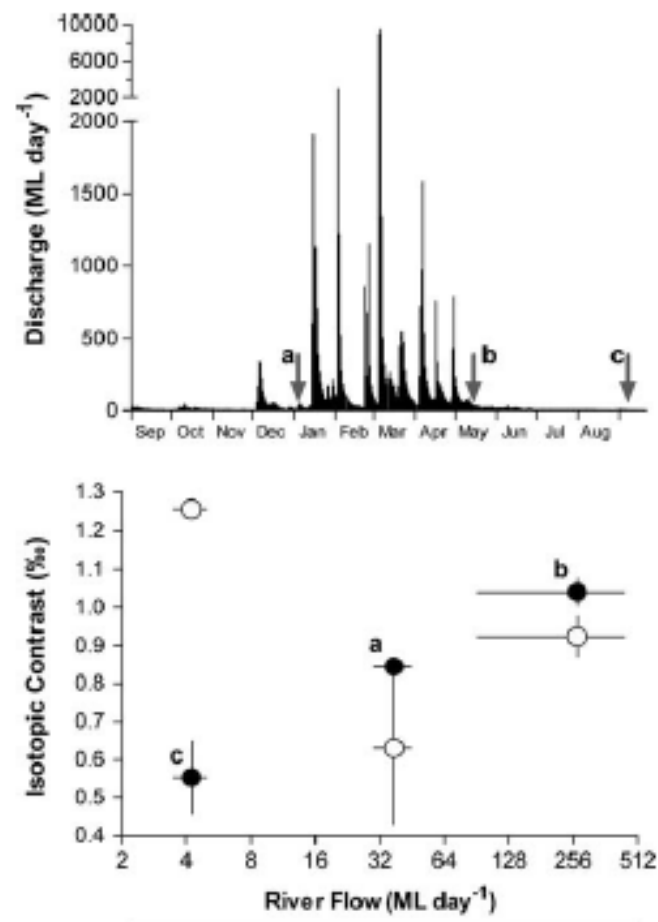

- ${ }^{13} \mathrm{C}$ isotopic Shift $\bigcirc{ }^{15} \mathrm{~N}$ lsotopic Shift

Figure 5 Variation in river discharge and sampling times for beach clams (top panel ; letters a-c), and isotopic contrast between clams from marine reference- and plume-impacted beaches $\left(\Delta_{\text {plume effect }}=\left|\delta_{\text {marine }}-\delta_{\text {plume }}\right|\right)$ as a function of discharge (lower panel). Letter symbols in lower panel correspond to sampling events (a-c) shown in top panel.

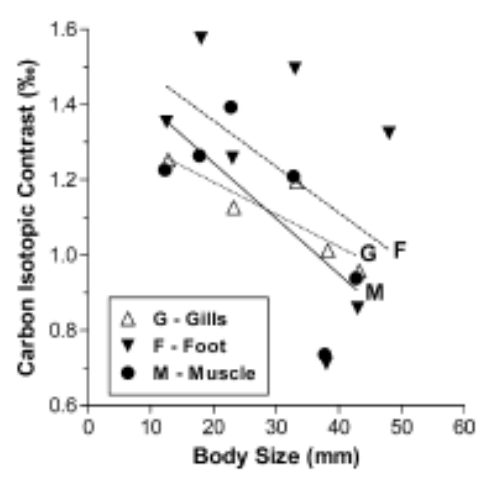

Figure 6 Contrasts in carbon isotope ratios $\left(\delta^{13} \mathrm{C}\right)$ between clams from a sandy beach impacted by river plumes and clams from ocean beaches without plumes $\left(\Delta \delta^{13} \mathrm{C}=\mid \delta 13\right.$ Cmarine ref $\left.-\delta^{13} \mathrm{C}_{\text {plume }} \mid\right)$ after peak river discharge (May 2004) in relation to body size (shell length; F-tests for regression slopes: Gills $-F=7.9$, $\mathrm{P}=0.07$; Foot $-\mathrm{F}=1.7, \mathrm{P}=0.25$; Muscle $-\mathrm{F}=4.5, \mathrm{P}=0.10$; All tissues $-\mathrm{F}=7.39, \mathrm{P}=0.01$ ). 
are an important fisheries resource (McLachlan and others 1996b), and extra carbon and nitrogen from river plumes may enhance fisheries yields of sandy beach invertebrates. 3) Rivers are exporting higher amounts of nutrients and pollutants, resulting mainly from burgeoning population growth and development in coastal watersheds, and the detrimental effects of nutrient enrichment and toxicants on coastal ecosystems are numerous, widespread and well-documented (Schlacher and others 2005; Howarth and Marino 2006). The assimilation of the sewage-derived nitrogen that we measured in beach organisms highlights a serious environmental issue of pollutant transfer across ecosystem boundaries. This pollutant transfer impacts on sandy beaches, which are the prime recreational resource for humans on ocean shores worldwide and are already under threat from a plethora of human pressures (Schlacher and others 2006; Schlacher and others 2007c; Schlacher and others 2007b). 4) Finally, global climate change is predicted to modify the volume and pattern of river flows (Meehl and others 2007), altering the amount of organic matter delivered to the coastal oceans globally. Our data show that marine intertidal ecosystems can be energetically linked to river inputs, suggesting that key properties of carbon and nitrogen cycling on ocean shores worldwide are vulnerable to impacts arising from climate change.

\section{ACKNOWLEDGEMENTS}

Financial assistance for this study was provided through Linkage grant of the Australian Research Council (ARC) to the authors, with the Moreton Bay \& Catchments Partnership as the industry partner. We thank Sean Conlan for help with field collections and Anna Skillington for assistance with bivalve dissections. 


\section{REFERENCES}

Anderson WB, Polis GA. 1998. Marine subsidies of island communities in the Gulf of California: evidence from stable carbon and nitrogen isotopes. Oikos 81:75-80.

Ansell AD (1983) The biology of the genus Donax. In: McLachlan A, Erasmus E (eds) Sandy Beaches as Ecosystems. Junk Publishers, The Hague, pp 607-636

Bianchi TS, Galler JJ, Allison MA. 2007. Hydrodynamic sorting and transport of terrestrially derived organic carbon in sediments of the Mississippi and Atchafalaya Rivers. Estuarine, Coastal and Shelf Science 73:211-222.

Burdon FJ, Harding JS. 2008. The linkage between riparian predators and aquatic insects across a stream-resource spectrum. Freshwater Biology 53:330-346.

Cadenasso ML, Pickett STA, Weathers KC, Jones CG. 2003. A framework for a theory of ecological boundaries. Bioscience 53:750-758.

Cadenasso ML, Pickett STA, Weathers KC (2004) Effects of landscape boundaries of the flux of nutrients, detritus and organisms. In: Polis GA, Power ME, Huxel GR (eds) Food webs at the landscape level. University of Chicago Press, Chicago, Illinois, USA, pp 154-168

Chanton J, Lewis FG. 2002. Examination of coupling between primary and secondary production in a river-dominated estuary: Apalachicola Bay, Florida, USA. Limnology and Oceanography 47:683-697.

Cockcroft AC, McLachlan A. 1993. Nitrogen budget for a high-energy ecosystem. Marine Ecology Progress Series 100:287-299.

Cole JJ, Carpenter SR, Pace ML, Van De Bogert MC, Kitchell JL, Hodgson JR. 2006. Differential support of lake food webs by three types of terrestrial organic carbon. Ecology Letters 9:558-568.

Connolly RM, Schlacher TA, Gaston TF. in press. Stable isotope evidence for trophic subsidy of coastal benthic fisheries by river discharge plumes generated off small estuaries. Marine Biological Research in press

Coupland GT, Duarte CM, Walker DI. 2007. High metabolic rates in beach cast communities. Ecosystems in press:online first; DOI 10.1007/s10021-007-9102-3

Dagg MJ, Benner R, Lohrenz S, Lawrence D. 2004. Transformation of dissolved and particulate materials on continental shelves influenced by large rivers: Plume processes. Continental Shelf Research 24:833-858.

Dame RF. 1996. Ecology of marine bivalves: an ecosystem approach. Florida: CRC Press, 254p.

Darnaude AM, Salen-Picard C, Polunin NVC, Harmelin-Vivien ML. 2004 Trophodynamic linkage between river runoff and coastal fishery yield elucidated by stable isotope data in the Gulf of Lions (NW Mediterranean). Oecologia 138: 325-32.

Donn Jr TE. 1990. Zonation patterns of Donax serra Roding (Bivalvia: Donacidea) in Southern Africa. Journal of Coastal Research 6:903-911.

Ellers O. 1995. Behavioral Control of Swash-Riding in the Clam Donax Variabilis. Biological Bulletin 189:120-127.

Ellis JC, Fariña JM, Witman JD. 2006. Nutrient transfer from sea to land: The case of gulls and cormorants in the Gulf of Maine. Journal of Animal Ecology 75:565-574. 
Gaston TF, Schlacher TA, Connolly RM. 2006. Flood discharges of a small river into open coastal waters: Plume traits and material fate. Estuarine, Coastal and Shelf Science 69:4-9.

Gillanders BM, Kingsford MJ. 2002. Impact of changes in flow of freshwater on estuarine and open coastal habitats and the associated organisms. Oceanography and Marine Biology - An Annual Review 40:233-309.

Goni MA, Ruttenberg KC, Eglinton TI. 1997. Sources and contribution of terrigenous organic carbon to surface sediments in the Gulf of Mexico. Nature 389:275-278.

Gustafson L, Showers W, Kwak T, Levine J, Stoskopf M. 2007. Temporal and spatial variability in stable isotope compositions of a freshwater mussel: Implications for biomonitoring and ecological studies. Oecologia 152:140-150.

Hansson S, Hobbie JE, Elmgren R, Larsson U, Fry B, Johansson S, 1997. The stable nitrogen isotope ratio as a marker of food-web interactions and fish migration. Ecology 78: 2249-57.

Hawkins AJS. 1985. Relationships between the synthesis and breakdown of protein, dietary absorption and turnovers of nitrogen and carbon in the blue mussel, Mytilus edulis L. Oecologia 66:42-49.

Hill JM, McQuaid CD, Kaehler S. 2006. Biogeographic and nearshore-offshore trends in isotope ratios of intertidal mussels and their food sources around the coast of southern Africa. Marine Ecology Progress Series 318:63-73.

Howarth RW, Marino R. 2006. Nitrogen as the limiting nutrient for eutrophication in coastal marine ecosystems: Evolving views over three decades. Limnology and Oceanography 51:364376.

Ittekkot V. 1988. Global trends in the nature of organic matter in river suspensions. Nature 332:436-438.

James RJ, Fairweather PG. 1995. Comparison of rapid methods for sampling the Pipi, Donax deltoides (Bivalvia, Donacidae), on sandy ocean beaches. Marine \& Freshwater Research 46:1093-1099.

James RJ, Fairweather PG. 1996. Spatial variation of intertidal macrofauna on a sandy ocean beach in Australia. Estuarine, Coastal and Shelf Science 43:81-107.

James RJ. 2000. From beaches to beach environments: linking the ecology, human-use and management of beaches in Australia. Ocean \& Coastal Management 43:495-514.

Knight TM, McCoy MW, Chase JM, McCoy KA, Holt RD. 2005. Trophic cascades across ecosystems. Nature 437:880-883.

Levin LA, DF Bosch, A Covich, C Dahm, C Erseus, KC Ewel, RT Kneib, A Moldenke, MA Palmer, $P$ Snelgrove, D Strayer, J M Weslawski. 2001. The function of marine critical transition zones and the importance of sediment biodiversity. Ecosystems 4:430-451

Loreau M, Mouquet N, Holt RD. 2003. Meta-ecosystems: A theoretical framework for a spatial ecosystem ecology. Ecology Letters 6:673-679.

Loreau M, Holt RD. 2004. Spatial flows and the regulation of ecosystems. American Naturalist 163:606-615.

Lorrain A, Paulet YM, Chauvaud L, Savoye N, Donval A, Saout C. 2002. Differential $\delta^{13} C$ and $\delta^{15} \mathrm{~N}$ signatures among scallop tissues: Implications for ecology and physiology. Journal of Experimental Marine Biology and Ecology 275:47-61. 
Ludwig W, Probst JL, Kempe S. 1996. Predicting the oceanic input of organic carbon by continental erosion. Global Biogeochemical Cycles 10:23-41.

Marczak LB, Thompson RM, Richardson JS. 2007. Meta-analysis: Trophic level, habitat, and productivity shape the food web effects of resource subsidies. Ecology 88:140-148.

Matthews S, Lucas MI, Stenton-Dozey JME, Brown AC. 1989. Clearance and yield of bacterioplankton and particulates for two suspension-feeding infaunal bivalves, Donax serra Roding and Mactra lilacea Lam. Journal of Experimental Marine Biology and Ecology 125:219-234.

McCann KS, Rasmussen JB, Umbanhowar J. 2005. The dynamics of spatially coupled food webs. Ecology Letters 8:513-523.

McClain ME, Boyer EW, Dent CL, Gergel SE, Grimm NB, Groffman PM, Hart SC, Harvey JW, Johnston CA, Mayorga E, McDowell WH, Pinay G. 2003. Biogeochemical hot spots and hot moments at the interface of terrestrial and aquatic ecosystems. Ecosystems 6:301312.

McClelland JW, Valiela I, Michener RH, 1997. Nitrogen-stable isotope signatures in estuarine food webs: A record of increasing urbanization in coastal watersheds. Limnology and Oceanography 42: 930-37.

McKee BA, Aller RC, Allison MA, Bianchi TS, Kineke GC. 2004. Transport and transformation of dissolved and particulate materials on continental margins influenced by major rivers: Benthic boundary layer and seabed processes. Continental Shelf Research 24:899-926.

McLachlan A, Dugan JE, Defeo O, Ansell AD, Hubbard DM, Jaramillo E, Penchaszadeh PE. 1996a. Beach clam fisheries. Oceanography and Marine Biology: An Annual Review 34:163-232.

McLachlan A, Dugan JE, Defeo O, Ansell AD, Hubbard DM, Jaramillo E, Penchaszadeh PE. 1996b. Beach clam fisheries. Oceanography and Marine Biology - An Annual Review 34:163-232.

McLachlan A, Brown AC. 2006. The ecology of sandy shores. Burlington (MA, USA): Academic Press, 373p.

Meehl GA, Stocker TF, Collins WD, Friedlingstein P, Gaye AT, Gregory JM, Kitoh A, Knutti R, Murphy JM, Noda A, Raper SCB, Watterson IG, Weaver AJ, Zhao Z-C (2007) Global Climate Projections. In: Solomon S, Qin D, Manning M, Chen Z, Marquis M, Averyt KB, Tignor M, Miller HL (eds) Climate Change 2007: The Physical Science Basis Contribution of Working Group I to the Fourth Assessment Report of the Intergovernmental Panel on Climate Change. Cambridge University Press, Cambridge, U.K., pp 747-846

Megens L, Van der Plicht J, De Leeuw JW. 2001. Temporal variation in ${ }^{13} \mathrm{C}$ and ${ }^{14} \mathrm{C}$ concentrations in particulate organic matter from the Southern North Sea. Geochimica et Cosmochimica Acta 65:2899-2911.

Michener RH, Schell DM (1994) Stable isotope ratios as tracers in marine aquatic food webs. In: Lajtha K, Michener RH (eds) Stable isotopes in ecology and environmental science. Blackwell, Oxford, pp 138-157

Pace ML, Carpenter SR, Cole JJ, Coloso JJ, Kitchell JF, Hodgson JR, Middelburg JJ, Preston ND, Solomon CT, Weidel BC. 2007. Does terrestrial organic carbon subsidize the planktonic food web in a clear-water lake? Limnology and Oceanography 52:2177-2189.

Paetzold A, Bernet JF, Tockner K. 2006. Consumer-specific responses to riverine subsidy pulses in a riparian arthropod assemblage. Freshwater Biology 51:1103-1115. 
Pan JF, Wang WX. 2004. Differential uptake of dissolved and particulate organic carbon by the marine mussel Perna viridis. Limnology and Oceanography 49:1980-1991.

Peterson BJ, Fry B. 1987. Stable isotopes in ecosystem studies. Annual Review of Ecology and Systematics 18:293-320.

Peterson CH, Bishop MJ, Johnson GA, D'Anna LM, Manning LM. 2006. Exploiting beach filling as an unaffordable experiment: benthic intertidal impacts propagating upwards to shorebirds. Journal of Experimental Marine Biology and Ecology 338:205-221.

Phillips DL, Gregg JW. 2001. Uncertainty in source partitioning using stable isotopes. Oecologia 127:171-179.

Polis GA, Hurd SD. 1995. Extraordinarily high spider densities on islands - flow of energy from the marine to terrestrial food webs and the absence of predation. Proceedings of the National Academy of Sciences of the United States of America 92:4382-4386.

Polis GA, Hurd SD. 1996. Linking marine and terrestrial food webs: Allochthonous input from the ocean supports high secondary productivity on small islands and coastal land communities. American Naturalist 147:396-423.

Polis GA, Anderson WB, Holt RD. 1997. Toward an integration of landscape and food web ecology: The dynamics of spatially subsidized food webs. Annual Review of Ecology and Systematics 28:289-316.

Post DM, Doyle MW, Sabo JL, Finlay JC. 2007. The problem of boundaries in defining ecosystems: A potential landmine for uniting geomorphology and ecology. Geomorphology 89:111-126.

Raikow DF, Hamilton SK. 2001. Bivalve diets in a midwestern U.S. stream: A stable isotope enrichment study. Limnology and Oceanography 46:514-522.

Rubbo MJ, Cole JJ, Kiesecker JM. 2006. Terrestrial subsidies of organic carbon support net ecosystem production in temporary forest ponds: Evidence from an ecosystem experiment. Ecosystems 9:1170-1176.

Salas C, Tirado C, Manjon-Cabeza ME. 2001. Sublethal foot-predation on Donacidae (Mollusca : Bivalvia). Journal of Sea Research 46:43-56.

Schlacher TA, Liddell B, Gaston TF, Schlacher-Hoenlinger M. 2005. Fish track wastewater pollution to estuaries. Oecologia 144:570-584.

Schlacher TA, Schoeman DS, Lastra M, Jones A, Dugan J, Scapini F, McLachlan A. 2006. Neglected ecosystems bear the brunt of change. Ethology, Ecology \& Evolution 18:349351.

Schlacher TA, Thompson LMC. 2007. Exposure of fauna to off-road vehicle (ORV) traffic on sandy beaches. Coastal Management 35:567-583.

Schlacher TA, Cronin G. 2007. A trophic cascade in a macrophytes-based food web at the landwater ecotone. Ecological Research 22:749-755.

Schlacher TA, Mondon JA, Connolly RM. 2007a. Estuarine fish health assessment: Evidence of wastewater impacts based on nitrogen isotopes and histopathology. Marine Pollution Bulletin 54:1762-1776.

Schlacher TA, Thompson LMC, Price S. 2007b. Vehicles versus conservation of invertebrates on sandy beaches: quantifying direct mortalities inflicted by off-road vehicles (ORVs) on ghost crabs. Marine Ecology 28:354-367. 
Schlacher TA, Dugan J, Schoeman DS, Lastra M, Jones A, Scapini F, McLachlan A, Defeo O. 2007c. Sandy beaches at the brink. Diversity \& Distributions 13:556-560.

Schlacher TA, Connolly RM, Skillington AJ, Gaston TF. in press-a. Can export of organic matter from estuaries support zooplankton in nearshore, marine plumes? Aquatic Ecology in press

Schlacher TA, Skillington AJ, Connolly RM, Robinson W, Gaston TF. in press-b. Coupling between marine plankton and freshwater flow in the plumes off a small estuary International Review of Hydrobiology in press

Schlünz B, Schneider RR. 1999. Transport of terrestrial organic carbon to the oceans by rivers: Re-estimating flux- and burial rates. International Journal of Earth Sciences 88:599-606.

Soares AG, Schlacher TA, McLachlan A. 1997. Carbon and nitrogen exchange between sandy beach clams (Donax serra) and kelp beds in the Benguela Coastal Upwelling Region. Marine Biology 127:657-664.

Stapp P, Polis GA. 2003. Marine resources subsidize insular rodent populations in the Gulf of California, Mexico. Oecologia 134:496-504.

Waldron S, Tatner P, Jack I, Arnott C, 2001. The impact of sewage discharge in a marine embayment: a stable isotope reconnaissance. Estuarine Coastal and Shelf Science 52: 111-15.

Wissel B, Fry B, 2005. Tracing Mississippi River influences in estuarine food webs of coastal Louisiana. Oecologia 144: 659-72.

Wollast R (1991) The coastal organic carbon cycle: fluxes, sources and sinks. In: Mantoura RFC, Martin JM, Wollast R (eds) Oceanic margin processes in global change. Wiley, Chichester, pp 365-3811

Zuanon JAS, Pezzato AC, Pezzato LE, Passos JRS, Barros MM, Ducatti C. 2006. Muscle $\delta^{13} \mathrm{C}$ change in Nile tilapia (Oreochromis niloticus): Effects of growth and carbon turnover. Comparative Biochemistry and Physiology - B Biochemistry and Molecular Biology 145:101-107. 